\title{
A Case of a Mesenteric Cyst in the Sigmoid Colon of a 3-year-old Girl
}

\author{
Shinya Iida ${ }^{1}$, Kiyonori Furukawa ${ }^{1,2}$, Yoshie Terada', \\ Yuichi Sugisaki ${ }^{3}$, Kazuyasu Yoshimura ${ }^{4}$ and Takashi Tajiri ${ }^{1}$ \\ ${ }^{1}$ Surgery for Organ Function and Biological Regulation, Graduate School of Medicine, Nippon Medical School \\ ${ }^{2}$ Department of Surgery, Nippon Medical School Chiba Hokusoh Hospital \\ ${ }^{3}$ Department of Diagnostic Pathology, Nippon Medical School Hospital \\ ${ }^{4}$ Department of Surgery, Hakuji-kai Memorial Hospital, Tokyo
}

\begin{abstract}
Mesenteric cysts are rare. In this paper we present a case of a mesenteric cyst in the sigmoid colon of a 3-year-old girl. On the first visit to our department, a smooth-surfaced soft mass approximately $15 \mathrm{~cm}$ in diameter was noticed in the right lower abdomen. Although the patient complained of lower abdominal pain, there was no tenderness or guarding. Laboratory tests indicated no abnormality except a slightly increased level of C-reactive protein $(2.3 \mathrm{mg} /$ dL). A plain abdominal X-ray film revealed displacement of colonic gas from the right lower abdomen, and abdominal ultrasonography and computed tomography revealed a smooth cystic mass measuring $9.5 \times 8.7 \times 4.7 \mathrm{~cm}$ that contained many internal septa. Because the patient had several symptoms, we performed a surgical operation under general anesthesia. We found a light-red cystic mass, $8.5 \times 8.0 \times 3.0 \mathrm{~cm}$ in size, in the mesentery of the sigmoid colon and surrounding the sigmoid colon, without adhesion to any other organ. We approached the cystic mass from the sigmoid colon and the mesentery of sigmoid colon and completely resected it without complications. The content of the cystic mass was a pale-yellow serous fluid. A cytological examination revealed mainly lymphocytes with reactive mesothelial cells. The resulting pathological diagnosis was a multi-lobular mesenteric cyst. Immunohistochemical staining with D2-40 antibody was positive value along the wall of the cyst, indicating that the cyst was derived from a lymphatic vessel.
\end{abstract}

(J Nippon Med Sch 2009; 76: 247-252)

Key words: mesenteric cyst, colon, lymphatic vessel

\section{Introduction}

Mesenteric cysts are rare, with a reported incidence of approximately 1 of 100,000 hospital admissions. The cysts usually occur in childhood. According to a report from Kuroiwa et al. in Japan, for example, about two-thirds of patients with mesenteric cysts are children younger than 10 years ${ }^{2}$. In a report from the West, however, the mean patient age at diagnosis of mesenteric and retroperitoneal cysts is 25 years, (range: 1 day to 83 years) $)^{3}$. In this paper we present a case of a mesenteric cyst in the sigmoid colon of a 3-year-old

Correspondence to Shinya Iida, Department of Surgery, Nippon Medical School, 1-1-5 Sendagi, Bunkyo-ku, Tokyo

113-8603, Japan

E-mail: shinyals@nms.ac.jp

Journal Website (http://www.nms.ac.jp/jnms/) 
S. Iida, et al

Table 1 Laboratory data at admission

\begin{tabular}{|c|c|c|c|c|c|}
\hline \multicolumn{4}{|c|}{ Blood test } & \multicolumn{2}{|l|}{ Urinalysis } \\
\hline WBC & $5,500 / \mathrm{mL}$ & $\mathrm{HBsAg}$ & - & Examination of urine & \\
\hline $\mathrm{RBC}$ & $420 \times 10^{4} / \mathrm{mL}$ & $\mathrm{HCVAb}$ & - & color & yellow \\
\hline $\mathrm{Hb}$ & $11.6 \mathrm{~g} / \mathrm{dL}$ & Wa RPR & - & cloudiness & - \\
\hline $\mathrm{Ht}$ & $34 \%$ & TPHA & - & $\mathrm{pH}$ & 7 \\
\hline Plt & $30.2 \times 10^{4} / \mathrm{mL}$ & HIVAb & - & specific gravity & 1.018 \\
\hline AST & $27 \mathrm{IU} / \mathrm{L}$ & CEA & $<0.5 \mathrm{ng} / \mathrm{mL}$ & protein & - \\
\hline ALT & $15 \mathrm{IU} / \mathrm{L}$ & $\mathrm{NSE}$ & $9.1 \mathrm{ng} / \mathrm{mL}$ & glucose & - \\
\hline $\mathrm{LDH}$ & $415 \mathrm{IU} / \mathrm{L}$ & $\mathrm{AFP}$ & $<1.0 \mathrm{ng} / \mathrm{mL}$ & urobilinogen & 0.1 \\
\hline ALP & $402 \mathrm{IU} / \mathrm{L}$ & CA19-9 & $11 \mathrm{U} / \mathrm{mL}$ & bilirubin & $-\mathrm{EU} / \mathrm{dL}$ \\
\hline g-GTP & $10 \mathrm{IU} / \mathrm{L}$ & IAP & $751 \mathrm{mg} / \mathrm{mL}$ & ketone body & - \\
\hline ChE & $255 \mathrm{IU} / \mathrm{L}$ & $\mathrm{HCGb}$ & $\overline{<0.1} \mathrm{ng} / \mathrm{mL}$ & occult blood & - \\
\hline $\mathrm{CPK}$ & $122 \mathrm{IU} / \mathrm{L}$ & & & white blood cell & $1+$ \\
\hline T-Bil & $0.1 \mathrm{mg} / \mathrm{dL}$ & bleeding time & $2 \min$ & nitrite & - \\
\hline T-Cho & $146 \mathrm{mg} / \mathrm{dL}$ & prothrombin time & $111.4 \%$ & \multicolumn{2}{|c|}{ Quantitative determination of urine } \\
\hline TG & $43 \mathrm{mg} / \mathrm{dL}$ & & 0.94 INR & protein & $<10 \mathrm{mg} / \mathrm{dL}$ \\
\hline $\mathrm{Na}$ & $144 \mathrm{mEq} / \mathrm{L}$ & activated partial & $30.1 \mathrm{sec}$ & glucose & $<0.01 \mathrm{~g} / \mathrm{dL}$ \\
\hline $\mathrm{K}$ & $4.3 \mathrm{mEq} / \mathrm{L}$ & thromboplastin time & & urine VMA & $1.5 \mathrm{mg} /$ day \\
\hline $\mathrm{Cl}$ & $107 \mathrm{mEq} / \mathrm{L}$ & fibrinogen & $294 \mathrm{mg} / \mathrm{dL}$ & urine HMA & $2.8 \mathrm{mg} /$ day \\
\hline UA & $4.3 \mathrm{mg} / \mathrm{dL}$ & thrombo test & $93.4 \%$ & urinary sediment & \\
\hline BUN & $10.3 \mathrm{mg} / \mathrm{dL}$ & hepaplastin test & $117.4 \%$ & red blood cell & $<1 / \mathrm{HP}$ \\
\hline Cre & $0.36 \mathrm{mg} / \mathrm{dL}$ & & & white blood cell & $1-4 / \mathrm{HP}$ \\
\hline $\mathrm{TP}$ & $6.5 \mathrm{~g} / \mathrm{dL}$ & & & squamous cell & $<1 / \mathrm{HP}$ \\
\hline Alb & $4.3 \mathrm{~g} / \mathrm{dL}$ & & & transitional epithelium & $<1 / \mathrm{HP}$ \\
\hline \multirow[t]{2}{*}{ CRP } & $2.3 \mathrm{mg} / \mathrm{dL}$ & & & bacterium & $1+$ \\
\hline & & & & Stool occult blood & - \\
\hline
\end{tabular}

girl. No morbidity or mortality was observed in the perioperative period, and the cyst did not recur.

\section{Case Report}

The patient was a girl born at the gestational age of 41 weeks after a normal pregnancy. Birth weight was 3,215 g. Abdominal swelling was noticed by her family after at the age of 1 year. At the age of 3 years, a fever of $38.8^{\circ} \mathrm{C}$ and constipation developed. Two days later, the fever had not abated, and lower right abdominal pain, appetite loss and diarrhea developed as well. The patient was brought to a clinic, which then referred her to another hospital with a probable diagnosis of acute appendicitis. Ultrasonography revealed a cystic mass in the right lower abdomen, so she was referred to our hospital for further examination and treatment.

On the patient's first visit to our department, a smooth-surfaced soft mass approximately $15 \mathrm{~cm}$ in diameter was found in the right lower abdomen. Although she complained of lower abdominal pain, there was no tenderness or guarding. She was 97.6 $\mathrm{cm}$ tall and weighed $16.8 \mathrm{~kg}$. The abdominal circumference was $55.5 \mathrm{~cm}$ at the navel and a maximum of $57.0 \mathrm{~cm}$. Body temperature was $36.7^{\circ} \mathrm{C}$, blood pressure was $102 / 60 \mathrm{mmHg}$, and the pulse rate was 106 beats per minute. Laboratory tests indicated no abnormality apart from a slightly increased level of C-reactive protein to $2.3 \mathrm{mg} / \mathrm{dL}$

\section{(Table 1).}

Clinical examination: A plain abdominal X-ray film revealed displacement of colonic gas from the right lower abdomen, but with no evidence of mass shadow, fluid level, or gas in the small intestine (Fig. 1A, 1B; arrows). A barium enema examination showed displacement of the sigmoid colon (Fig. 1C). Abdominal ultrasonography revealed a smooth cystic mass measuring $9.5 \times 8.7 \times 4.7 \mathrm{~cm}$. It was evident that the mass contained many septa and was not connected to the bladder (Fig. 2A). Abdominal computed tomography also revealed a smooth-surfaced low-density area containing many septa which was thought to be a multiclustered 

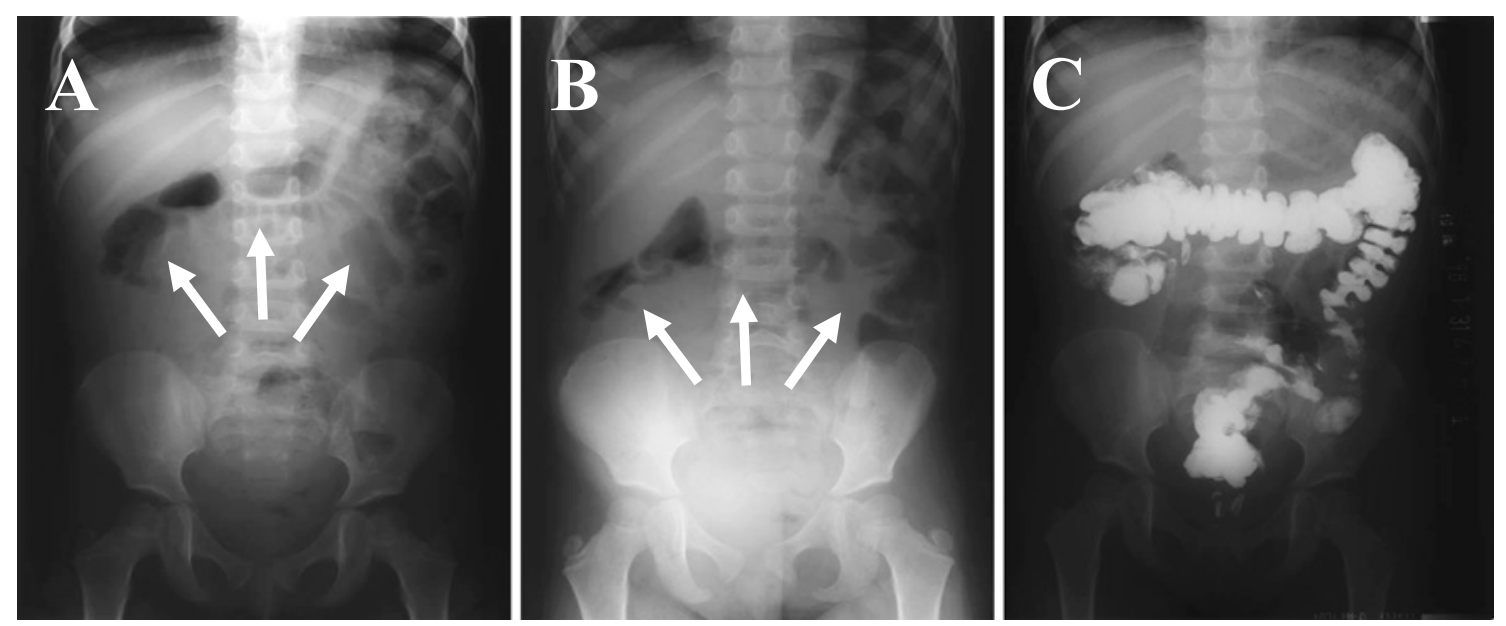

Fig. 1 Simple abdominal X-ray film in the supine position (A) and the standing position (B) revealed displacement of colonic gas from the right lower abdomen (arrows) but no sign of mass shadow, niveau or gas from the small intestine. A barium enema examination (C) showed displacement of the sigmoid colon.
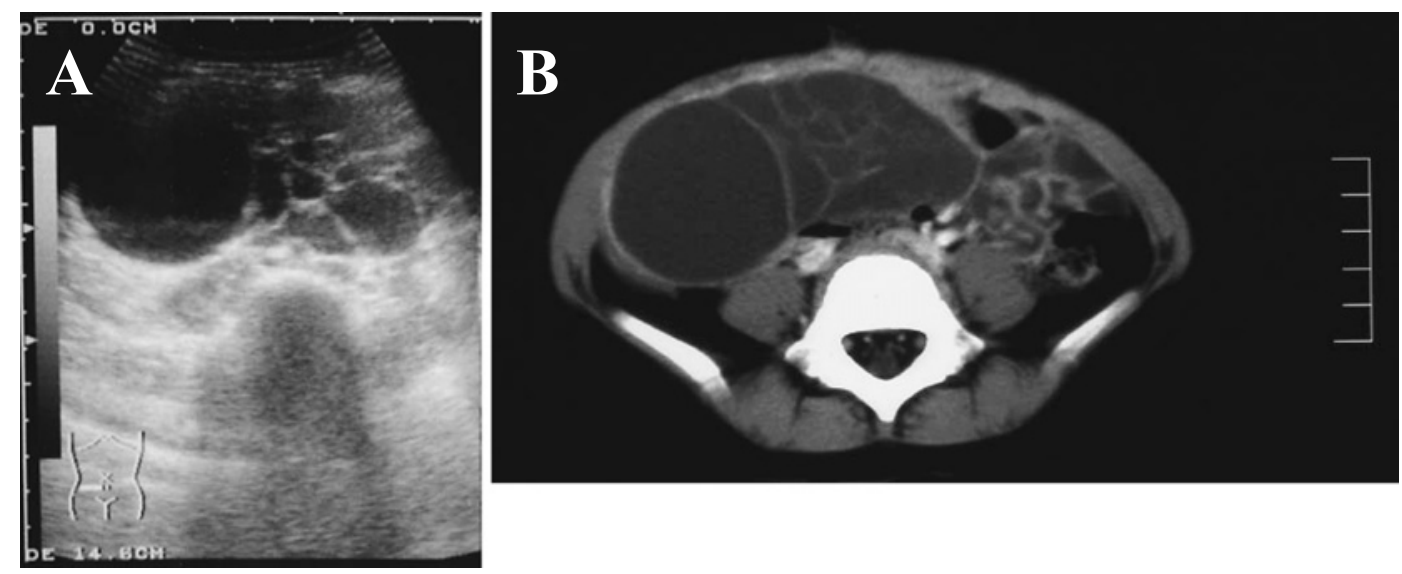

Fig. 2 Abdominal ultrasonography (A) and computed tomography (B) revealed a cystic mass with a smooth surface. Many septa were seen inside the mass.

cystic mass. There was no evidence of a solid mass or lymph node swelling and no indication of ascites on computed tomography (Fig. 2B). Drip infusion pyelography showed no abnormality in the urinary tract (data not shown).

These examinations resulted in a diagnosis of mesenteric cyst. Other possibilities considered in the differential diagnosis included duplication of the intestines, ovarian cyst, teratoma, Wilms tumor, and neuroblastoma.

Surgical procedure: The operation was performed under general anesthesia. Approaching via a transrectal incision in the right side of the abdomen (Fig. 3A), we found a light-red cystic mass measuring $8.5 \times 8.0 \times 3.0 \mathrm{~cm}$ at the mesentery of the sigmoid colon. We also detected a small amount of yellowish serous ascitic fluid in the Douglas pouch. There was no adhesion to any other organ (Fig. 3B and $3 \mathrm{C}$ ). We approached the cystic mass from the sigmoid colon and the meso-sigmoid colon, and completely resected it without any complications.

The content of the cystic mass was a serous paleyellow fluid. The results of the blood and biochemical tests of this fluid are shown in Table 2 A. Cytological examination revealed mainly lymphocytes with reactive mesothelial cells (Table 2 B). These results were similar to the results of the cytological examination of the ascitic fluid (Table 2 C).

Hematoxylin and eosin staining revealed that the 


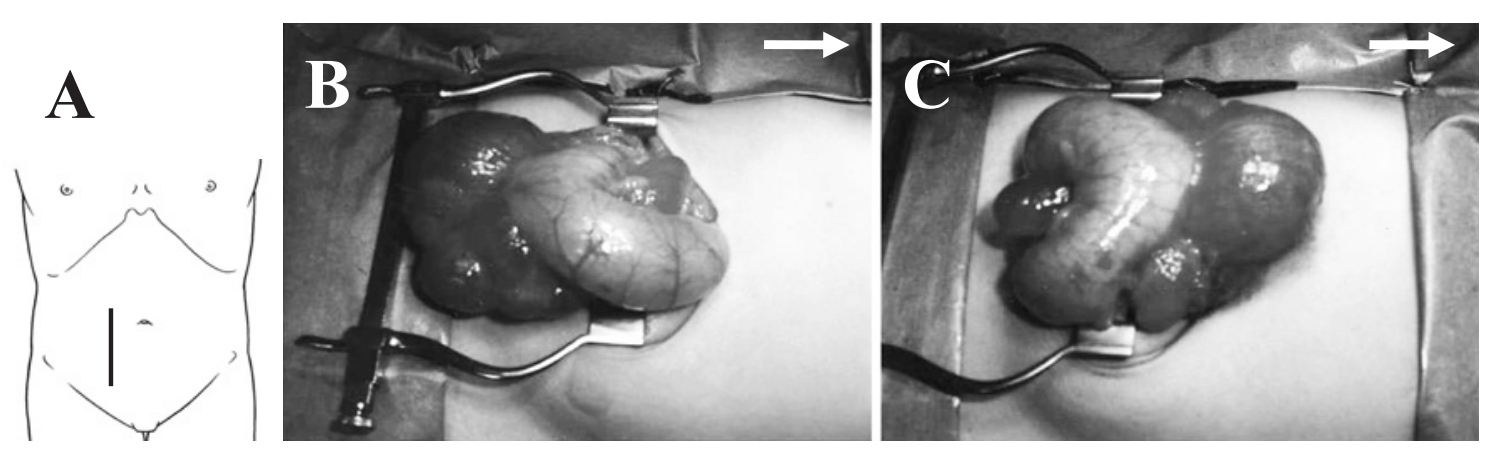

Fig. 3 A: A transrectal incision was made in the right side of the abdomen (line). B, C: A light-red cystic mass measuring $8.5 \times 8.0 \times 3.0 \mathrm{~cm}$ was discovered at the meso-sigmoid colon surrounding the sigmoid colon. There was no adhesion to any other organ. Arrows point toward the patient's head.

Table 2 Blood test and biochemical test of the intracystic fluid

\begin{tabular}{lccc}
\hline A: Biochemical data of the intracystic fluid & B: Cytology of the intracystic fluid \\
\hline $\mathrm{Na}$ & $144 \mathrm{mEq} / \mathrm{L}$ & Class II & \\
$\mathrm{K}$ & $4.2 \mathrm{mEq} / \mathrm{L}$ & red blood cell & + \\
$\mathrm{Cl}$ & $109 \mathrm{mEq} / \mathrm{L}$ & neutrophile & + \\
$\mathrm{Ca}$ & $8.4 \mathrm{mg} / \mathrm{dL}$ & lymphocyte & +++ \\
$\mathrm{Fe}$ & $53 \mathrm{mg} / \mathrm{dL}$ & histiocyte (monocyte) & + \\
osmotic pressure & $297 \mathrm{mOsm}$ & phagocyte & ++ \\
$\mathrm{TP}$ & $5.1 \mathrm{~g} / \mathrm{dL}$ & & \\
Alb & $3.6 \mathrm{~g} / \mathrm{dL}$ & & \\
FBS & $86 \mathrm{mg} / \mathrm{dL}$ & & + \\
CEA & $0.7 \mathrm{ng} / \mathrm{mL}$ & C: Cytology of the ascites & \\
NSE & $5.3 \mathrm{ng} / \mathrm{mL}$ & Class II & ++ \\
AFP & $1.6 \mathrm{ng} / \mathrm{mL}$ & mesothelial cell & + \\
SCC & $1.2 \mathrm{ng} / \mathrm{mL}$ & red blood cell & + \\
CA19-9 & $<6 \mathrm{U} / \mathrm{mL}$ & neutrophil & ++ \\
ferritin & $2,800 \mathrm{ng} / \mathrm{mL}$ & lymphocyte & ++ \\
pH & 8 & histiocyte (monocyte) & ++ \\
specific gravity & 1.021 & & \\
nuclear cell counts & $723 / \mathrm{mL}$ & & \\
Rivalta reaction & + & & \\
Runeberg reaction & + & & \\
& & &
\end{tabular}

cystic wall was composed of fibrous tissue containing thin, flat lining cells. These findings led to a pathological diagnosis of mesenteric cyst (Fig. 4A). Immunohistochemical analysis with the lymphatic endothelial marker D2-40 showed expression along the lining cells of the cyst (Fig. 4B), whereas CD34 was not expressed (Fig. 4C). These findings indicated that the cyst was derived from a lymphatic vessel.

Post-operative course: The naso-gastric tube was removed on the first post-operative day. The patient began to drink water at noon on the second postoperative day, and started eating rice gruel in the evening of the same day. She was discharged on the 11th postoperative day.

\section{Discussion}

"Mesenteric cyst" is a generic term for cysts occurring in the mesentery. Such cysts were first reported by Benivieni in $1507^{4}$. This condition usually occurs in children, as demonstrated in a study in Japan by Kuroiwa et al. ${ }^{2}$ which revealed that $63 \%$ of 378 patients with mesenteric cysts in Japan were children younger than ten years. The gender ratio of this disease is $1.36: 1^{2}$. In Japan mesenteric cyst is more common in men, but in Western countries it is more common in women ${ }^{2}$. 

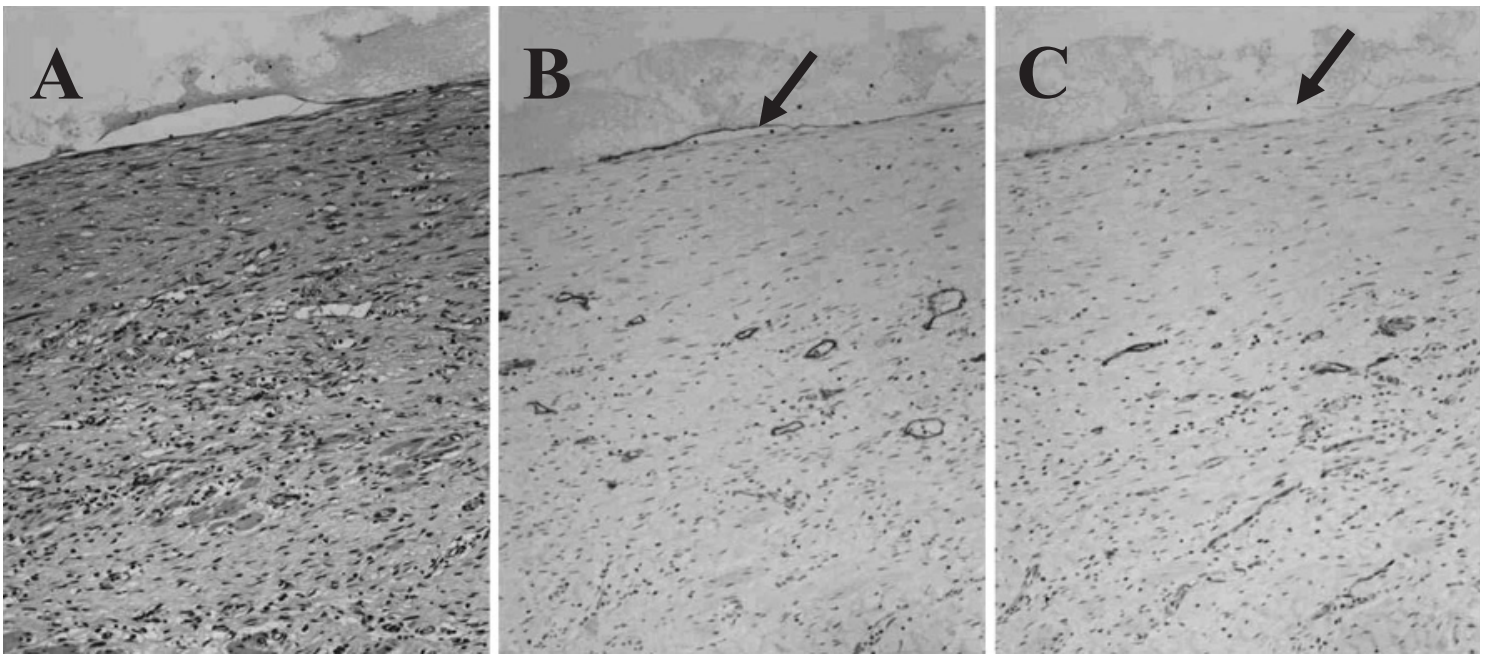

Fig. 4 The cystic wall was composed of fibrous tissue with a few small vessels and infiltration of small round cells (A). Immunohistochemical analysis indicated that the inner lining cells of the cyst and some small vessels in the cystic wall were positive for D2-40 (B) but negative for CD34. CD34-positivity was noted on the other small vessels (C). The arrows indicate the inner lining cells of the cyst (B, C).

Moriwaki et al. reported that the ratio of mesenteric cysts in adults was $60 \%$ in the small intestine and $40 \%$ in the colon, while for children the ratio was $74 \%$ in the small intestine and $26 \%$ in the colon ${ }^{5}$, while Kuroiwa et al. reported that $67 \%$ of mesenteric cysts occurred in the small intestine and $33 \%$ in the colon $^{2}$. Of the $33 \%$ of cases of colonic mesenteric cysts, almost all cases were detected at the transverse or sigmoid colon ${ }^{2}$. Kurtz, et al. studied a population of 162 Western patients with mesenteric and retroperitoneal cysts divided into two groups based on age $(<10 \text { years old vs. }>10 \text { years old })^{3}$. When all the cases were considered, the numbers of males and females in their study were approximately equal ${ }^{3}$. Yet in the comparison between the age groups, males were significantly more frequent in younger group ${ }^{3}$. There seems to be no obvious reason for this difference ${ }^{3}$. Moreover, the locations of the cysts differed significantly between the younger and older groups ${ }^{3}$. Among the 58 patients younger than 10 years, the cysts were located in the small bowel mesentery in 45 patients (78\%), in the large bowel mesentery in 9 patients (15\%), and in the retroperitoneal space in 4 patients $(7 \%)^{3}$. In the 92 patients of the older group, the cysts were located in the small bowel mesentery in 47 patients $(51 \%)$, in large bowel mesentery in 28 patients $(30 \%)$, and in the retroperitoneal space in 18 patients $(19 \%)^{3}$. Among cases of this disease, it is more common for cysts to be multiclustered rather than monoclustered, whereas multiple cysts are more common than solitary cysts².

Neukirch's classification has been used to classify mesenteric cysts ${ }^{6}$. However, the cause of this disease is controversial and there are two possible hypotheses: one theory identifies cysts as acquired, stating that fluid collection within a cyst is caused by the obstruction of lymph vessels due to trauma, inflammation, or pregnancy; the other theory postulates that cysts are congenital and that the fluid collection results from the proliferation of aberrant lymph tissue during embryonic development $^{2}$. A previous Western report has suggested that cysts are caused by sequestration or budding of lymphatic vessels, obstruction of lymphatic vessels, or ectopic lymphatic tissue ${ }^{1}$.

Most small cysts cause no symptoms, whereas larger cysts more often produce such symptoms as abdominal pain, nausea, vomiting, abdominal fullness, and constipation ${ }^{2}$. Symptoms often appeared suddenly if complications, such as volvulus, intestinal obstruction, and rupture of the cyst, have occurred ${ }^{2}$.

Because the symptoms of mesenteric cysts are varied and atypical, diagnosis is sometimes difficult. However, diagnosis in the present case was relatively easy as was selecting the correct diagnosis from among the conditions suggested by the differential diagnosis. 
The treatment of choice for mesenteric cysts is complete excision ${ }^{3}$. Segmental bowel resection may be necessary if the adjacent bowel has a compromised blood supply ${ }^{1}$. Some recently reported mesenteric cysts have been resected with laparoscopic surgery ${ }^{7.8}$.

Because mesenteric cyst is a benign disease, its prognosis is generally good. However, rare cases involving a multicystic pattern or those leading to severe complications or the development of malignant tumors all of which have been reported in adult patients ${ }^{3,9}$, can be fatal.

\section{References}

1. Okur H, Küçükaydin M, Özokutan BH, Durak AC Kazez A, Köse Ö: Mesenteric, Omental, and Retroperitoneal Cysts in Children. Eur J Surg 1997; 163: 673-677.

2. Kuroiwa M, Matsuyama S, Suzuki N, et al.: Cystic Lymphangioma of the Mesentery in ChildrenReport of Two Patients Diagnosed Before
Operaton-. J Jpn Soc Pedriatr Surg 1988; 24: 11221131 (in Japanese).

3. Kurtz RJ, Heimann TM, Beck AR, Holt J: Mesenteric and Retroperitoneal Cysts. Ann Surg 1986; 203: 109112.

4. Benivieni A: De abiditis nonnullis acmarandis morborum et sanationem cousis, 1507; Florence, Italy.

5. Moriwaki Y, Shinmyo K, Hosoi H, et al: An Adult Case of Mesenteric Cyst. Jpn J Gastroenterol Surg 1992; 25: 2431-2435 (in Japanese).

6. Neukirch F: Cysten und-Pseudocysten des Mesenteriums. Arch Klin Chir 1930; 161: 730-746 (in German).

7. Suzuki H, Furukawa K, Takasaki H, Nomura T, Shinji S, Tajiri T: Laparoscopic excision of mesenteric cystic lymphangioma-a case report. J Jpn Soc Endosc Surg 2005; 10: 225-228 (in Japanese).

8. Mackenzie DJ, Shapiro SJ, Gordon LA, Ress R: Laparoscopic excision of a mesenteric cyst. J Laparoendosc Surg 1993; 3: 295-299.

9. Harakawa I, Hachisuka K, Yamaguchi A, et al.: Jpn J Gastroenterol Surg 1987; 20: 2397-2400 (in Japanese).

(Received, June 22, 2009)

(Accepted, August 17, 2009) 